ÇOMÜ Uluslararası Sosyal Bilimler Dergisi 4 (2), 167-180 , 2019 COMU International Journal of Social Sciences 4 (2), 167-180 , 2019

\title{
İrrasyonel İnanışların İş Tatminine Etkisinde Algılanan Örgüt Desteğinin Aracı Rolü
}

Bora COŞAR *

$\ddot{O} z$

Araştırmanın amacı irrasyonel inanışların iş tatminine etkisinde algılanan örgüt desteğinin aracı rolünün ortaya konmasıdır. Kolayda örnekleme yöntemine göre İstanbul Beylikdüzü bölgesinde bulunan banka şubesi çalışanlarıyla anket yapılarak elde edilen veriler, Baron ve Kenny'nin (1986) üç aşamalı metodolojisi ışığında analiz edilmiştir. 272 kişinin katılımıyla gerçekleştirilen çalışmada, örgüt üyelerinden demografik etkenlerle ilgili beş, irrasyonel inanışlarla ilgili 17, algılanan örgütsel destekle ilgili sekiz ve iş tatminiyle ilgili 14 ifadeye cevap vermeleri istenmiştir. Bu bağlamda SPSS 25 ve Excel 2016 programlarında gerçekleştirilen analizler ışığında algılanan örgütsel desteğin, irrasyonel inanışların iş tatminine etkisinde kısmi bir şekilde aracı rolü olduğu görülmüștür.

Anahtar Kelimeler: İrrasyonel İnanışlar, Problemden Kaçma, Onaylanma İhtiyacı, Algılanan Örgütsel Destek, İş Tatmini.

\section{The Mediating Role Of Perceived Organizational Support On The Relationship Between Irrational Beliefs And Work Satisfaction}

\begin{abstract}
The aim of the study is to reveal the mediating role of perceived organizational support in the effect of irrational beliefs on job satisfaction. In terms of simple sampling method, the data obtained by conducting a survey with the employees of the bank branches located in the Beylikdüzü district of Istanbul, were analyzed in the light of the three-stage methodology of Baron and Kenny (1986). The study was conducted with the participation of 272 people. The participants were asked to answer five items of the scale, related to demographic factors, 17 related to irrational beliefs, eight related to perceived organizational support and 14 related to job satisfaction. In the light of the analyses performed in SPSS 25 and Excel 2016 programs, it has been identified that perceived organizational support has a partial mediator role in the effect of irrational beliefs on job satisfaction.
\end{abstract}

Key Words: Irrational Beliefs, Avoiding Problems, Need for Approval, Perceived Organizational Support, Job Satisfaction.

\footnotetext{
* Dr. Öğr. Üyesi, Beykent Üniversitesi, Yönetim ve Organizasyon Bölümü, Lojistik Programı,

boracosar@beykent.edu.tr
} 


\section{GİRIŞ}

Günümüz iş dünyasında yaşanan ve küresel boyutta olan yoğun rekabet şartları, ekonomik problemler ve bunlara bağlı olarak işletmelerin ayakta kalma çabası, örgüt içi çalışanlar açısından da oldukça sıkıntılı ve sarsıcı dönemlerin yaşanmasına sebep olmaktadır. Bu bağlamda örgüt üyelerinin psikolojik durumu ve yöneticilerin bu durumu yönetebilme yeteneği günümüzün en önemli kavramları olarak karşımıza çıkmaktadır. Örgüt üyelerinin olumlu yönde performans göstermesi ve iş yerlerine katkı sağlamasında yöneticilerin önemli rolü bulunmaktadır. İyi yönetilen ve kendini psikolojik olarak iyi hisseden örgüt üyelerinin işle ilgili daha yüksek düzeyde tatmin olacağ fikrinden hareket ederek bu çalışmanın modeli oluşturulmuştur. Araştırma son zamanlarda ekonominin de düzensizliğine bağlı olarak sürekli ürün ve hizmetlerde değişimler yaşayan özel sektördeki banka çalışanları ile gerçekleştirilmiştir. Bu noktada örgüt düzeyi çerçevesinde çalışanların irrasyonel inanışları ve iki alt boyutu olan onaylanma ihtiyacı ve problemlerden kaçma, araştırmanın bağımsız değişkenleri olarak belirlenmiştir. İrrasyonel inanışların temeli, bilişsel-davranışsal ve akılcı duygusal terapi olarak bilinen en eski bilişsel-davranışçı terapi şeklinden gelmektedir. 1955 yılında Albert Ellis tarafından ortaya konan bu terapi şekli, insanların psikolojik sorunlarının akılcı olmayan inançlardan kaynaklandığını belirtmektedir (Dryden, 1994: 83). Bu inançlardan biri olan onaylanma ihtiyacı değişkeni, başkaları tarafından onaylanma gerekliliği ile birlikte başarısızlık ve reddedilme korkusunu ele almaktadır. Bir diğer değişken olan problemlerden kaçma ise karar verme, risk alma ve sorumluluk alma gibi ölçütlerden oluşmaktadır (Bridges ve Sanderman, 2002: 67-68).

Araştırmanın aracı değişkeni, irrasyonel inanışlarla iş tatmini arasında köprü vazifesi görebileceğine inanılan ve yöneticiler ile diğer örgüt üyeleri tarafından çalışanlara sağlanması beklenen algılanan örgütsel destektir. Algılanan örgütsel destek, yöneticiler ve diğer örgüt üyeleri tarafından gerçekleştirilen ve çalışanlar tarafından hissedilen ve buna bağlı olarak kişinin stres ile ilgili duygularında tampon görevi gören davranış biçimleri olarak özetlenebilmektedir (Wethington ve Kessler, 1986: 79). Araştırmanın bağımlı değişkeni olan iş tatmininin ise bu aracı değişkene bağlı olarak artış gösterileceği ön görülmektedir. İş tatmini, çalışanın işinden memnun olduğunu doğru söylemesine neden olan psikolojik, fizyolojik ve çevresel koşulların bir kombinasyonu olarak karşımıza çıkmaktadır (Aziri, 2011: 77). Bu bağlamda araştırmada ortaya konan tüm değişkenlerin ortak noktası psikolojik bir şekilde örgüt üyeleri üzerinde olumlu ya da olumsuz şekilde etki bırakmalarıdır. Araştırma özellikle irrasyonel inanışların belli bir oranda da olsa iş hayatında belli kriterler çerçevesinde ve belirli desteklerle aşılıp aşılamadığını görmek amacı ile gerçekleştirilmektedir. Ortaya konan değişkenlerin ortak noktası psikoloji disiplini ile ilgili konuları kapsamış olsa da araştırmanın banka şubelerindeki çalışanlarla gerçekleştirilmesi ve işyerinde sağlanan destek ve tatmin boyutlarını içermesi, çalışmayı psikoloji ile işletme yönetiminin en önemli unsurlarından olan örgütsel davranış disiplinlerinden oluşan multidisipliner bir hale getirmektedir. Bu noktada araştırmanın sorusu ve aynı zamanda modeli şu şekilde karşımıza çıkmaktadır:

"İrrasyonel inanışların alt boyutları olan problemden kaçma ve onaylanma ihtiyacının 
iş tatminine etkisinde algılanan örgütsel desteğin aracı rolü bulunmakta mıdır?”. Araştırmanın modeli daha önce literatürde herhangi bir çalışmada gerçekleştirilmemiş olup bu sayede literatüre katkıda bulunulması hedeflenmektedir. Ayrıca akademisyenlere ve iş hayatında yer alan profesyonellere katkı sağlamak ve yol gösterici olmak da bu araştırmanın en önemli amaçlarından biridir.

\section{TEORİK LITTERATÜR}

İrasyonel inanışların depresyon ve diğer psikolojik bozukluklarla ilgili rolü üzerine yüksek sayıda araştırma gerçekleştirilmiştir. İrrasyonel inanışlar, gerçekçi olmayan bir şekilde kişinin dışarıdaki olayları yorumladığı ve bu yorumlamaların duygusal sıkıntıya aracılık ettiği akıl yürütme süreçleri olarak tanımlanmaktadır. İrrasyonel bilişleri değerlendirmek için çeşitli ölçümler geliştirilmiştir. Bunlardan en sık kullanılanı İrrasyonel İnanışlar Testi ve Rasyonel Davranış Envanteri olarak bilinmektedir (Bridges ve Sanderman, 2002: 6667). ABCDE modeli ise bilişsel-davranışsal ve akılcı duygusal terapinin temel taşı olarak adlandırılmaktadır. Bu modele göre, insanlar rasyonel ve mantıksız inançları olan (B) istenmeyen aktive edici olaylar (A) yaşamaktadır. Bu inançlar duygusal, davranışsal ve bilişsel sonuçlara yol açmaktadır (C). Rasyonel inançlar fonksiyonel sonuçlara, irrasyonel inançlar işlevsiz sonuçlara neden olurlar. Bu noktada kişi irrasyonel inançlarını aktif olarak tartışmaya yani yeniden yapılandırmaya (D) ve duygusal, bilişsel ve davranışsal tepkilerinde olumlu bir etkiye sahip daha verimli, uyumlu ve rasyonel inançları benimsemeye teşvik edilir (E) (Szentagotai ve diğerleri, 2005: 140).

Ellis tarafından ortaya konan bu yaklaşım, ilk başlarda yüksek düzeyde bilişsel, pozitivist ve aşırı yönlendirici bir yaklaşım portresi çizerken, zamanla duygu ve davranışları da önemseyen bir gelişime uğramıştır. Ellis’e göre (1994) insanlar, yanlış düşünme ve akılcı olmayan inançlar neticesinde depresif, kaygılı, sıkıntılı bir ruh haline bürünmekte ve buna bağlı olarak belirli sorunlar yaşamaktadır. Yani kısaca eğer akılcı inançlar varsa akılcı duygu ve davranışlar meydana gelmekte, akılcı olmayan inançlar mevcutsa akılcı olmayan duygu ve davranışlar ortaya çıkmaktadır. Bu durum duygu, düşünce ve davranış arasındaki ilişkiler ağından kaynaklanmaktadır. Duygular, davranışlar ve inançlar birbirleri üzerinde farklı durumlara göre etkili olmaktadır. Ellis’e göre depresyonun temel nedeni bu irrasyonel inanışlardır. Bu noktada kişinin bu inançlarını tartışmaya gönüllü olması ve bu durumu yapılandırması kişinin rasyonel davranması için önemli adımlardır (Tanhan, 2014: 59).

İrrasyonel davranışların bu araştırmada kullanılacak iki bağımsız değişkeni onaylanma ihtiyacı ve problemden kaçma olarak belirlenmiştir. Onaylanma ihtiyacı ile ilgili olarak kişi insanlar tarafından sevilmek ve onaylanmak istemektedir ve başarısızlıktan korkmaktadır. İnsanların ne düşündüğü bu kişiler için oldukça önemlidir ve bu durumla ilgili kaygıları vardır. Problemden kaçma ile ilgili ise sorunlarla yüzleşmek istememek, yapmaktan hoşlanmadığı işlerden kaçmak, bir zorluk ya da kriz meydana geldiğinde 
bocalamak, önemli kararları ertelemek, sorumluluk almamak gibi durumlar ortaya çıkmaktadır (Koopmans ve diğerleri, 1994: 27).

Onaylanma ihtiyacı ve problemlerden kaçma gibi kişiyi ve örgütü olumsuz düzeyde etkileyecek durumlar karşısında örgüt yöneticilerinin ve üyelerinin bu durumdaki kişileri desteklemeleri ve motive etme çabaları, örgütün bu kişilerden fayda sağlaması adına oldukça önemlidir. Ancak burada önemli olan nokta bu kişilerin bu örgütsel desteği olumlu algılaması ve anlamlandırmasıdır. Başka bir ifadeyle örgüt içinde meydana gelen olay ve durumların bir anlam kazanabilmesi yani algılanabilmesi için kişinin duygusal izlenimleri neticesinde yorumladıkları bir sürecin ortaya çıkması gerekmektedir (Robbins ve diğerleri, 2013: 166). Örgüt üyelerinin iş ve günlük hayatlarında çevresinde meydana gelen durum ve olaylara yükledikleri anlamlar aynı zamanda davranışlarını da etkilemektedir. Kısaca kişiler çevresel unsurlardan etkilenmekte, olayları ve durumları algılayış biçimlerine göre düşünceler üretmekte ve sonuç olarak çevresini etkileyen davranışlar ortaya koymaktadır (Erdoğan, 1996: 28). Algılanan örgütsel destek, örgüt üyesinin işini etkili bir şekilde yerine getirmesi ve stresli olduğu durumlarla başa çıkması gerektiği zaman örgütten yardım alabileceğinin teminatı olarak değerlendirilmektedir (Rhoades ve Eisenberger, 2002: 698). Bu noktada bir takım irrasyonal inanışlar içinde olan örgüt bireylerinin örgütten yardım alabileceğini bilmesi ve örgüt üyelerini arkasında hissetmesi onun performansı ve gelişimi adına oldukça önemli bir durumdur. 1990’lı yıllardan beri özellikle psikoloji ve yönetim alanlarında yüksek düzeyde ilgi gören algılanan örgütsel destek kavramı, günümüzün yoğun ve karmaşık ilişkiler ağına dayalı iş hayatında önemi giderek artan bir güç olarak karşımıza çıkmaktadır. Özellikle ekonomik sorunların ve krizlerin yoğun olarak görüldügü günümüzün küresel pazarlarında örgütsel ve bireysel anlamda sürdürülebilirliğin devam edebilmesi için de kritik öneme sahiptir (Aube ve Diğerleri, 2007: 479-480).

Bu kadar büyük bir öneme sahip olan algılanan örgütsel destek kavramı, örgütlerin sürdürülebilirliği adına oldukça önemlidir. Çünkü örgüt üyeleri bir takım psikolojik sorunlarla karşı karşıya kalsalar bile örgüt tarafından desteklendikleri ile ilgili oluşan algı onların motivasyonuna ve dolayısıyla işe olan bağlılıklarına ve iş tatminine olumlu yönde etki edebilmektedir (Aube ve Diğerleri, 2007: 479). Örgütlerin sürdürülebilirliği açısından önemli bir kavram olarak karşımıza çıkan iş tatmini, 1970'li yıllardan günümüze kadar hala önemli ve ilgi çekici konularından biri olmayı sürdürmektedir.

Jalagat'a göre (2016: 36) iş tatmini, iş performansı ve motivasyon birbirleri ile etkileşimde bulunmaktadır ve birbirlerine bağlı olarak hareket eder. Böylece ortaya çıkan hareket doğrusal olmaktan ziyade daireseldir. İş tatmini ve örgütsel performans, örgüt bireylerinin grup performansıyla ilişkilendirildiğinde sonuç her zaman olumlu yönde anlamlı olmamaktadır ancak yüksek iş memnuniyetinin daha yüksek bir performansa yol açtığ 1 görülmektedir. Birlikte bir grup olarak çalışmak istenen sonuca ulaşmak için bir anahtardır ama bu noktada örgüt üyelerinin sıkı koşullar altında baskı ile çalıştırılmaları birçok problemi de yanında getirmektedir. Bu noktada örgüt üyelerinin örgüt hedeflerine ve dolayısıyla başarıya ulaşabilmeleri için teşvik ve tatmin edilmeleri oldukça büyük önem 
taşımaktadır. İş tatmini yadsınamaz bir biçimde örgütlerin etkinliğini ve verimliliğini değerlendirmede en önemli hususlardan biri olarak görülmektedir. Nitekim günümüz koşullarında modern yönetim perspektifi altındaki örgütler, örgüt üyelerinin kişisel ihtiyaçlarını ve isteklerini dikkate alarak iş tatmini sağlama yoluna gitmeye çalışmaktadır. $\mathrm{Bu}$ bağlamda bir örgüt üyesinin işin koşulları ile ilgili mutlu ve tatmin olması, onun muhtemelen başarılı bir çalışan olacağını bizlere göstermektedir (Jalagat, 2016: 37).

\section{ARAŞTIRMANIN AMACI, MODELİ VE BULGULARI}

Araştırmanın amacı Beylikdüzü bölgesinde yer alan özel sektör banka çalışanlarının irrasyonel inanışlarının iş tatminine etkisinde algılanan örgütsel desteğin aracı rolünün olup olmadığının belirlenmesidir. Çalışma, kolayda örnekleme yöntemi yoluyla Beylikdüzü bölgesinde özel sektörde yer alan banka şubelerinde gerçekleştirilmiş ve 272 adet anket toplanmıştır. Buna bağlı olarak katılımcılara irrasyonel inanıșların alt boyutları olan problemden kaçma ile ilgili 10, onaylanma ihtiyacı ile ilgili ise yedi ifade ile ilgili sorular sorulmuş olup, ölçek Koopmans ve diğerleri (1994) tarafindan geliştirilmiştir. Algılanan örgütsel destek ile ilgili katılımcılara sekiz ifade sorulmuş ve ölçek Eisenberger ve diğerleri (1986) tarafından geliştirilmiştir. Son olarak iş tatmini ölçeği 14 ifadeden meydana gelmiştir ve ölçek Hackman ve Oldham (1975) tarafından geliştirilmiştir. Çalışmaya katkı veren katılımcılara ait demografik veriler Tablo 1'de görüldügüu gibidir. Yapılan araştırmaya bağlı olarak ortaya konan hipotezler ise şu şekildedir:

$\mathrm{H}_{1}$ : İrrasyonel inanışlar, iş tatmini değişkenini negatif yönlü olarak etkilemektedir.

$\mathrm{H}_{1 \mathrm{a}}$ : İrrasyonel inanışların alt boyutu problemden kaçma, iş tatmini değişkenini negatif yönlü olarak etkilemektedir.

$\mathrm{H}_{1 \mathrm{~b}}$ : İrrasyonel inanışların alt boyutu onaylanma ihtiyacı, iş tatmini değişkenini negatif yönlü olarak etkilemektedir.

$\mathrm{H}_{2}$ : Algılanan örgütsel destek, iş tatminini pozitif yönlü olarak etkilemektedir.

$\mathrm{H}_{3}$ : Algılanan örgütsel destek değişkeninin, irrasyonel inanışların iş tatminine etkisinde aracı rolü bulunmaktadır.

$\mathrm{H}_{3 \mathrm{a}}$ : Algılanan örgütsel destek değişkeninin, irrasyonel inanışların alt boyutu olan problemden kaçmanın iş tatminine etkisinde aracı rolü bulunmaktadır.

$\mathrm{H}_{3 \mathrm{~b}}$ : Algılanan örgütsel destek değişkeninin, irrasyonel inanışların alt boyutu olan onaylanma ihtiyacının iş tatminine etkisinde aracı rolü bulunmaktadır.

Yukarıdaki hipotezleri test etmek amacıyla, yapıların ölçümü için çok maddeli ölçekler 
kullanılmıştır. Her yapı, "kesinlikle katılmıyorum" (1) ile "kesinlikle katılıyorum" (7) arasında değişen yedi-nokta Likert ölçeği kullanılarak ölçülmüştür.

Tablo 1: Örneklem Grubunun Demografik Bilgileri

\begin{tabular}{lcc}
\hline Demografik Verileri & Sıklık & Oran \\
Cinsiyet & & \\
Kadın & 105 & 38.6 \\
Erkek & 167 & 61.4 \\
Kurumda Çalışma Süresi & & \\
$0-5$ & 147 & 54.1 \\
$6-10$ & 48 & 17.6 \\
$11-15$ & 34 & 12.5 \\
16 ve üzeri & 43 & 15.8 \\
Yaş & & \\
$20-25$ & 47 & 17.2 \\
$30-34$ & 83 & 30.5 \\
$35-39$ & 77 & 28.4 \\
40 ve üzeri & 65 & 23.9 \\
& & \\
Eğitim & & 19.1 \\
Ön Lisans & 52 & 74.3 \\
Lisans & 202 & 6.6 \\
Lisans Üstü & 18 & \\
Çalışlan Pozisyon & & 79.4 \\
Çalışan & & 20.6 \\
Yönetici & 216 & \\
& 56 & \\
& &
\end{tabular}

Araştırmanın güvenilirliği, composite scale reliability (CR), Cronbach's alpha ve elde edilen ortalama varyans (AVE) ile değerlendirilmiştir. Tablo 2'de görüldügüü gibi CR ve Cronbach's alpha değerlerinin 0.70 değerini aştığı görülmüşsür. AVE değerlerinde de tüm değerlerin 0.50'nin üzerinde olduğu tespit edilmiştir. Ayrıca değişkenler arasındaki korelasyon değerlerinin de $\mathrm{p}<0.01$ düzeyinde anlamlı oldukları görülmektedir. 
Tablo 2: Cronbach's alpha, CR, AVE, Anlamlılık, Standart Sapma ve Korelasyon Değerleri

\begin{tabular}{|c|c|c|c|c|c|c|}
\hline Değişkenler & Anl. & S.S. & 1 & 2 & 3 & 4 \\
\hline $\begin{array}{l}\text { İrrasyonel İnanışlar } 1 \\
\text { Problemden Kaçma } \\
\text { (Ters ölçek) }\end{array}$ & 3.322 & 1.485 & 1 & & & \\
\hline $\begin{array}{l}\text { İrrasyonel İnanışlar } 2 \\
\text { Onaylanma İhtiyacı } \\
\text { (Ters ölçek) }\end{array}$ & 2.830 & 1.240 & $0.566^{* *}$ & 1 & & \\
\hline $\begin{array}{l}\text { Alg1lanan Örgütsel } \\
\text { Destek }\end{array}$ & 5.295 & 1.112 & $-0.410^{* *}$ & $-0.492^{* *}$ & 1 & \\
\hline \multirow[t]{4}{*}{ İş Tatmini } & 5.761 & 1.048 & $-0.499^{* *}$ & $-0.601^{* *}$ & $0.518^{* *}$ & 1 \\
\hline & & $a$ & 0.916 & 0.915 & 0.933 & 0.962 \\
\hline & & $\mathrm{CR}$ & 0.900 & 0.886 & 0.918 & 0.949 \\
\hline & & AVE & 0.603 & 0.507 & 0.651 & 0.574 \\
\hline
\end{tabular}

** işaretli bileşenler arasındaki bire bir ilişkiler $\mathrm{p}<0,01$, *işaretliler ise $\mathrm{p}<0.05$ düzeyinde istatistiksel olarak anlamlı kabul edilmiştir.

Araştırmanın modeli bağlı bulunduğu hipotezler doğrultusunda şu şekilde oluşturulmuştur:

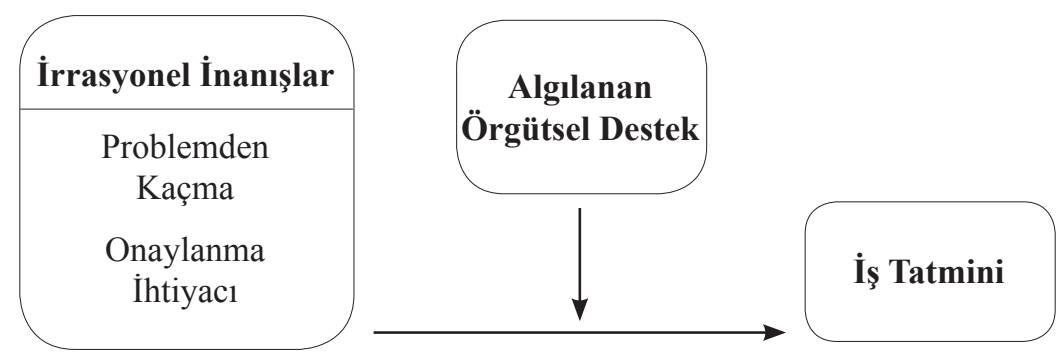

Şekil 1: Araştırmanın Modeli

Gerçekleştirilen analizler 1şı̆̆ında irrasyonel inanışların alt boyutu olan problemden kaçma değişkeninin $\left(\mathrm{H}_{1 \mathrm{a}}\right)$, iş tatmini üzerinde negatif yönlü $(\beta=-0.49, \mathrm{p}<0.01)$ etkisinin olduğu görülmektedir. Yine irrasyonel inanışların bir diğer alt boyutu olan onaylanma ihtiyacı değişkeninin de $\left(\mathrm{H}_{1 \mathrm{~b}}\right)$ iş tatmini üzerinde negatif yönlü $(\beta=-0.60, \mathrm{p}<0.01)$ bir etkisinin olduğu tespit edilmiştir. Bu sonuçlara göre araştırmanın $\mathrm{H}_{1}$ hipotezi tamamen 
desteklenmektedir.

$\mathrm{H}_{2}$ hipotezi ile ilgili bulgular incelendiğinde algılanan örgütsel desteğin iş tatminini pozitif yönlü $(\beta=0.51, p<0.01)$ bir şekilde etkilediği görülmektedir. Bu sonuçlar ışı̆̆ında $\mathrm{H}_{2}$ hipotezinin tamamen desteklendiği görülmektedir.

Araştırmanın $\mathrm{H}_{3}$ hipotezi ile ilgili olarak aracı değişken ile ilgili analizlerinin gerçekleştirilmesinde Baron ve Kenny (1986) tarafından ortaya konan üç koşul göz önünde bulundurulmuştur. Bunlar;

1. Bağımsız değiş̧kenin, aracı değişken üzerinde bir etkisi olmalıdır.

2. Bağımsız değişken, bağımlı değişken üzerinde etkili olmalıdır.

3. Aracı değişken, ikinci adımdaki regresyon analizine eklendiğinde; bağımsız değişkenle bağımlı değişken arasında anlamlı olmayan ilişki ortaya çıkarsa tam aracılık etkisinden; bağımsız değişken ile bağımlı değişken arasındaki ilişkide azalma meydana gelirse kısmi aracılık etkisinden söz etmek mümkündür.

Birinci koşula bağlı olarak gerçekleştirilen regresyon analizine göre irrasyonel inanışların alt boyutu olan problemden kaçma değişkeninin algılanan örgütsel destek değişkenine etkisi $(\beta=-0.41, p<0.01)$ yüksek düzeyde anlamlı çıkmıştır. İkinci koşulun sağlanması ile ilgili yapılan regresyon analizine göre irrasyonel inanışların alt boyutu olan problemden kaçma değişkeninin iş tatminine olan etkisi de $(\beta=-0.49, \mathrm{p}<0.01)$ yüksek düzeyde anlamlı bulunmuştur. Ayrıca bu noktada $\mathrm{R}^{2}$ değerinin 0.24 olduğu görülmektedir. Son koşula göre yapılan analizlerde ise irrasyonel inanışların alt boyutu olan problemden kaçma değişkeninin iş tatminine olan etkisi $(\beta=-0.34, \mathrm{p}<0.01)$ anlamını kaybetmemiştir. Ancak iki değişken arasındaki ilişki azaldığg için algılanan örgütsel destek değişkeninin, irrasyonel inanışların alt boyutu olan problemden kaçmanın iş tatminine etkisinde $\left(\mathrm{H}_{3 \mathrm{a}}\right)$ kısmi aracı rolünün olduğu tespit edilmiştir. $\mathrm{Bu}$ aşamada $\mathrm{R}^{2}$ değerinin de 0.36 olduğu görülmektedir. Aracı değişkenin devreye girmesiyle beraber $\mathrm{R}^{2}$ değerinin 0.24 'den 0.36 seviyesine çıkması modeldeki aracı değişkenin pozitif yönlü gücünün derecesini açıklamaktadır. 


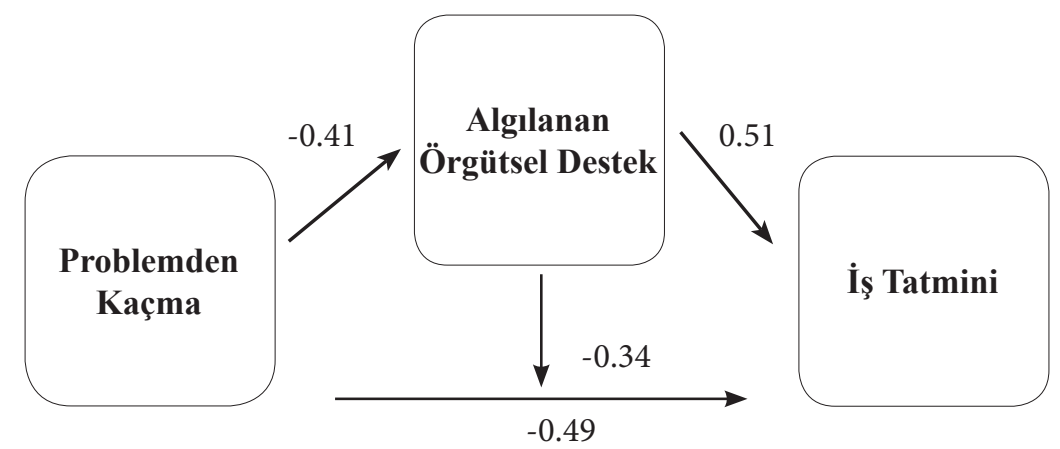

Şekil 2: Problemden Kaçma Değişkenine Göre Modelin Aracılık Etkisi

İrrasyonel inanışların diğer alt boyutu olan onaylanma ihtiyacı ile ilgili analizlere bakıldığında ise birinci koşul bağlamında gerçekleştirilen regresyon analizine göre onaylanma ihtiyacının algılanan örgütsel destek değişkenine etkisi $(\beta=-0.49, p<0.01)$ yüksek düzeyde anlamlı çıkmıştır. İkinci koşula göre yapılan analizler neticesinde onaylanma ihtiyacının iş tatminine olan etkisi de $(\beta=-0.60, \mathrm{p}<0.01)$ yine yüksek düzeyde anlamlılık göstermiştir. Bu noktada ölçülen $\mathrm{R}^{2}$ değeri 0.36 olarak tespit edilmiştir. Üçüncü koşula bağlı olarak yapılan analizler sonucunda irrasyonel inanışların alt boyutu olan onaylanma ihtiyacı değişkeninin iş tatminine etkisi $(\beta=-0.38, p<0.01)$ anlamını kaybetmemiş ancak iki değişken arasındaki gücün şiddetinin azaldığı görülmüştür. Bu sonuçlara bağlı olarak algılanan örgütsel destek değişkeninin, irrasyonel inanışların alt boyutu olan onaylanma ihtiyacının iş tatminine etkisinde $\left(\mathrm{H}_{3 \mathrm{~b}}\right)$ kısmi aracı rolünün olduğu tespit edilmiştir. $\mathrm{R}^{2}$ değeri ise 0.38 olarak belirlenmiş olup aracı değişkenin bu değeri 0.36'dan bu seviyeye taşıdığı görülmüştür. $\mathrm{Bu}$ da aracı değişkenin pozitif yönlü gücünün derecesini açıklamaktadır. Bu analizlere göre $\mathrm{H}_{3}$ hipotezi kısmi bir şekilde desteklenmiştir.

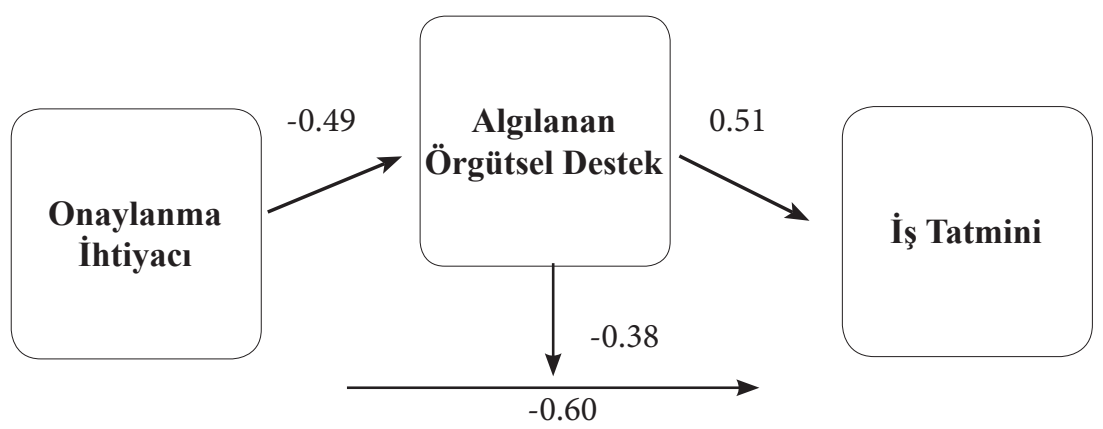

Şekil 3: Onaylanma İhtiyacı Değişkenine Göre Modelin Aracılık Etkisi 
Tüm bu bilgiler ışığında araştırmanın hipotezleri aşağıdaki tabloda görüldüğü gibi sonuçlanmıştır:

Tablo 3: Hipotez Sonuçları

\begin{tabular}{|l|l|l|l|l|l|}
\hline İlişkiler & Beta Değ. & $\begin{array}{l}\text { Alt } \\
\text { Hip. }\end{array}$ & Alt Sonuçlar & Hip & Sonuçlar \\
\hline $\begin{array}{l}\text { PK } \rightarrow \text { IT } \\
\text { Oİ } \rightarrow \text { IT }\end{array}$ & $\begin{array}{l}\text { H1a } \\
-0.49 * *\end{array}$ & $\begin{array}{l}\text { Desteklendi } \\
\text { Desteklendi }\end{array}$ & H1 & Desteklendi \\
\hline AÖD $\rightarrow$ İT & $0.51^{* *}$ & & & H2 & Desteklendi \\
\hline $\begin{array}{l}\text { PK x AÖD } \rightarrow \text { ITT } \\
\text { Oİ x AÖD } \rightarrow \text { IT }\end{array}$ & $\begin{array}{l}-0.49^{* *} \rightarrow-0.34^{* *} \\
-0.60^{* *} \rightarrow-0.38^{* *}\end{array}$ & $\begin{array}{l}\mathrm{H} 3 \mathrm{a} \\
\mathrm{H} 3 \mathrm{~b}\end{array}$ & $\begin{array}{l}\text { Kısmi olarak desteklendi } \\
\text { Kısmi olarak desteklendi }\end{array}$ & $\mathrm{H3}$ & $\begin{array}{l}\text { Kısmi olarak } \\
\text { desteklendi }\end{array}$ \\
\hline
\end{tabular}

** işaretli bileşenler arasındaki bire bir ilişkiler $\mathrm{p}<0,01,{ }^{*}$ işaretliler ise $\mathrm{p}<0.05$ düzeyinde istatistiksel olarak anlamlı kabul edilmiştir.

PK: Problemden Kaçma, Oİ: Onaylanma İhtiyac1, AÖD: Algılanan Örgütsel Destek, İT: İs Tatmini

\section{SONUÇ}

Küresel pazarlarda meydana gelen yoğun rekabet şartları, ekonomik düzensizlikler ve özellikle bankacılık sektöründe sürekli değişen ve farklılaşan ürün ve çalışma koşulları örgüt üyeleri üzerinde ciddi düzeyde baskı yaratmaktadır. Bu noktada kişinin geçmişine bağlı olarak ya da olmayarak, örgüt üyelerinde bir takım psikolojik sıkıntılar günümüz dünyasında artış göstermektedir (Ak ve Arıcıŏglu, 2018: 591). Buna bağlı olarak kişiler birtakım irrasyonel inanışlar doğrultusunda farklı tavır ve davranışlar sergileyebilmektedir. Bu noktada bu inanışlara sahip olan örgüt üyeleri, hem kendini hem de bulunduğu örgütü ciddi sıkıntılara sokabilmektedir. Bu araştırma bu duruma sahip olan örgüt üyelerinin irrasyonel inanışlara bağlı davranışlarının örgüt bağlamında nasıl azaltılabileceğinin ve bu durumun nasıl iş tatminini artırıcı bir duruma dönüşebileceğinin yollarını aramıştır. $\mathrm{Bu}$ noktada modele algılanan örgütsel destek kavramı aracı değişken olarak eklenmiş ve bunun irrasyonel inanışlar ile iş tatmini arasında bir köprü oluşturup oluşturmadı̆̆ 1 incelenmiştir.

Öncelikle irrasyonel inanışların iki boyutu olarak araştırmadaki yerlerini alan problemden kaçma ve onaylanma ihtiyacı değişkenlerinin iş tatminini yüksek düzeyde negatif olarak etkilediği görülmektedir. Araştırmanın ilk aşamasında ortaya çıkan bu bulgular hiç de şaşırtıcı değildir. Çünkü iş yerinde ortaya çıkan problemlerle yüzleşmekten korkan, yapmaktan hoşlanmadığı işlerden kaçınan, kriz ve zorluklarla karşı karşıya kaldığı zaman afallayan, önemli kararları erteleme yoluna giden ve sorumluluk almayı sevmeyen kişilerin iş tatmininden öte herhangi bir tatmin yaşaması da oldukça zor olacaktır. Yine herkesten 
sevgi ve onay bekleyen ve bu konularla ilgili kaygılar yaşayan, başarısızlık korkusuyla işini yapmaya çalışan, insanların kendisi ile ilgili ne düşündügünü sürekli olarak sorgulayan kişilerin de tatmin olması ve işine odaklanması ciddi bir problem olarak karşımıza çıkmaktadır (Koopmans ve Diğerleri, 1994: 27). Bu noktada yöneticilerin katılımcı bir yöntem izlemesi ve çalışanlar ile yönetim arasında psikolojik bir ortaklık kurması oldukça önemlidir. Böylece araştırma modelinde kilit bir rol oynayan algılanan örgütsel destek kavramı sayesinde çalışanlar motive edilebilir ve bu durum da verimliliğe pozitif bir şekilde yansıyabilir (İbicioğlu ve Çağlar, 1999: 182).

Özellikle araştırmanın gerçekleştirildiği bankacılık sektöründe yöneticilerin karşılaşılan değişiklik ve farklılıkları uygulamaya koyması ve bu durumu örgüt içine en sağlıklı şekilde entegre etmesi oldukça önem taşımaktadır. Her yöneticinin örgüt içindeki bu değişikliklere ve örgüt içi dinamiklere bağlı olarak oluşabilecek psikolojik sorunları anlaması ve çözümlemeye yardımcı olması gerekmektedir. Ayrıca bu durumlara bağlı olarak yöneticinin de zihinsel sağlığını koruması oldukça önemli bir husustur. Çünkü bu olmadan hem kendisinin hem de örgüt üyelerinin etkin bir çalışma kapasitesine ulaşması mümkün değildir (Weinberg ve Doyle, 2017: 33).

Araştırmanın diğer bir sonucu algılanan örgütsel desteğin iş tatminini artırdığı yönündedir. Burada asıl altının çizilmesi gereken nokta örgüt üyelerinin verilen bu desteği algılaması ve iş tatminine ulaşmasıdır. Başka bir deyişle örgütsel desteğin sağlanmasından çok algılanması durumu işgören tutumları üzerinde daha etkili olmaktadır. Örgüt üyelerine örgütsel bir destek sağlandığında bu örgüt üyeleri tarafından algılanmadığı takdirde etkisi yüksek düzeyde olmamaktadır (Polatçı ve diğerleri, 2014: 269). Kısacası güçlü örgütsel destek algısına sahip örgüt üyeleri örgüte fayda sağlayan davranışlar gösterme eğilimindedir; çünkü kendilerine gereken önem ve değerin verildiğini kavrayarak iş tatminine ulaşmaktadırlar (Eisenberger ve diğerleri, 1990: 51). Ancak burada önemli nokta, örgütün insan kaynağına verdiği önemin derecesidir. Bu önem arttığı ve örgüt üyelerine hissettirildiği sürece algılanan destek düzeyi yüksek olacak ve bu durum iş tatminine olumlu bir şekilde yansıyacaktır (Polatçı, 2015: 26).

Araştırmanın sorusu ve kilit noktası olan algılanan örgütsel desteğin aracı olduğu hipotezlerde ise irrasyonel inanışların alt boyutları olan problemden kaçma ve onaylanma ihtiyacı değişkenlerinin aracı olan algılanan örgütsel destek sayesinde iş tatmini ile ilgili negatif durumunun belirli düzeyde azalma gösterdiği görülmektedir. Bu bağlamda algılanan örgütsel desteğin irrasyonel inanışların negatif etkisini belirli ölçüde azalttı̆̆ ve iş tatminine olumlu yönde katkı yaptığını söylemek mümkündür. Ayrıca bu durum $\mathrm{R}^{2}$ değerlerinde de gözlemlenmektedir. Problemden kaçma değişkeninin iş tatminine etkisinde $\mathrm{R}^{2}$ değeri 0.24 iken, aracı etkili modelde bu oranın 0.36 olduğu görülmektedir. $\mathrm{Bu}$ artış aracı değişkenin model üzerinde etkili olduğunu ve bağımsız ve aracı değişkenlerin \% 36 gibi bir oranla bu etkiyi açıkladıklarını göstermektedir. Yine onaylanma ihtiyacının iş tatminine etkisinde meydana gelen $\mathrm{R}^{2}$ değeri 0.36'dır. Modele aracı değişken olan algılanan örgüt desteği eklendiğinde ise bu değer 0.38 olarak ölçülmüştür. Bu artış arac1 modelin etkisinden kaynaklanmış olup bağımsız ve aracı değişkenlerin \% 38 gibi bir 
oranla bu etkiyi açıkladıkları görülmektedir. Kısaca irrasyonel inanışların iki değişkeni de aracı değişken olan algılanan örgüt desteğinin pozitif gücü sayesinde iş tatmini, gücünü azaltan negatif değerlerle etkilemektedir.

Sonuç olarak banka şubesi örgüt üyesinin yaptığı işlerle ilgili olarak çekimser kalması, herhangi bir problemle karşı karşıya kaldığında hata yapacağını düşünerek geri adım atması ya da diğer örgüt üyelerinin kendisi ile ilgili olumsuz fikirlere sahip olduğunu düşünmesi, algılayabileceği örgüt içi bir destekle daha olumlu ve cesur kararlar verebilme durumuna dönüşebilmektedir. Burada ortaya konan örgütsel destek, yönetici ve diğer örgüt üyelerinin cesaretlendirici ve motive edebileceği konuşmaları olabileceği gibi eğitim, terfi veya gerçekçi bir prim sistemi de olabilmektedir (Özdevecioğlu, 2003: 116). Özellikle iş dünyasında örgüt üyesi tarafından ortaya konan irrasyonel inanışlara bağlı davranışlar bazen kişinin kendisinden kaynaklanabileceği gibi bazen de iş yeri ortamının yapısına bağlı olarak da ortaya çıkabilmektedir. Bu noktada irrasyonel davranışlar kişinin kendisinden kaynaklanıyorsa ona örgütsel olarak destek vermek kaygılarını azaltabilecek ve iş tatminine pozitif yönde katkı sağlayabilecektir. Böylece kişinin psikolojik durumuna ya da tedavisine örgüt olarak destek verilmesi sağlanacak ve kişi daha rasyonel tutum ve davranışlar sergileyebilecektir. Bununla birlikte irrasyonel inanışlara bağlı olarak gelişen davranışlar örgüt yapısına bağlı olarak gelişiyorsa başta yöneticiler olmak üzere tüm örgüt üyeleri ile görüşmeler yapılarak sorunların hep beraber irdelenmesi yerinde olacaktır. Katılımcı bir çalışma ortamının sağlanması ve örgüt içi sorunların beraberce çözümlenmeye çalışılması tüm örgüt üyelerinin örgütle bağ kurmalarını sağlayabilecek ve bu durum onların iş tatminlerine de olumlu yansıyabilecektir. Günümüzün en önemli konuları içinde kendine yer bulan şeffaflık, hesap verebilirlik, kararlara birlikte katılım sağlamak gibi unsurlar örgüt üyelerinin kendilerini daha önemli hissetmelerine yardımcı olacaktır (Kesim, 2005: 273). Bu sayede örgütler iş yerlerinde tatmin olma duygusu yaşayan, örgütü ile bağ kuran ve iş tatminine ulaşarak örgüt performansına olumlu katkılarda bulunan üyelerden meydana gelebilecektir.

Araştırmanın bir takım kısıtları bulunmaktadır. İlk olarak çalışmanın Beylikdüzü sınırları içinde yer alan banka şubesi çalışanlarından oluşması en önemli kısıttır. Araştırmanın farklı bölge, il hatta ülkelerde gerçekleştirilmesi ve başka sektörlerde yapılması farklı sonuçların çıkmasına neden olabilir. İkinci önemli kısıt modelde yer alan irrasyonel inanışların sadece problemden kaçma ve onaylanma ihtiyacı değişkenleri ile temsil ediliyor olmasıdır. Diğer değişkenlerin ele alınmasıyla model genişletilebilir ya da daraltılabilir. Araştırmanın 272 kişi ile gerçekleştirilmesi ise diğer önemli bir kısıt olarak karşımıza çıkmaktadır. Buna bağlı olarak sayının artırılıp azaltılması da araştırmanın seyrini değiştirebilir. Son olarak irrasyonel inanışlara bağlı olarak ortaya konan davranışların örgütsel bağlamda daha fazla irdelenmesi, farklı değişkenlerle modellenmesi ve buna bağlı olarak yönetim ve organizasyon ile işletme yönetimi penceresinden ele alınması konunun önemi itibariyle oldukça yerinde olacaktır. Böylece bu davranışlara neden olan örgütsel durumlar ortaya konabilecek ve çözüm yoluna gitmek amacıyla daha fazla araştırma gerçekleşecektir. Bu sayede hem literatüre hem de iş dünyasına önemli katkılar sağlanabilecektir. 


\section{KAYNAKLAR}

Ak, Ö. K. ve Arıcıŏlu, M. A. (2018). Küreselleşmede Kültürel Geçişler ve Psikolojik Yansımaları. OPUS Uluslararası Toplum Araştırmaları Dergisi, 8(14), s.578-598.

Aube, C., Rousseau, V. ve Morin, E. M. (2007). Perceived Organizational Support and Organizational Commitment: The Moderating Effect of Locus of Control and Work autonomy. Journal of Managerial Psychology, 22(5), s.479-495.

Aziri, B. (2011). Job Satisfaction: A Literature Review. Management Research and Practice, 3(4), s.77-86.

Baron, R.M. ve Kenny, D.A. (1986) The Moderator-Mediator Variable Distinction in Social Psychological Research: Conceptual, Strategic, and Statistical Considerations, Journal of Personality and Social Psychology, 51(6), s. 1173-1182.

Bridges, K. R. ve Sanderman, R. (2002). The Irrational Beliefs Inventory: Cross Cultural Comparisons between American and Dutch Samples. Journal of Rational-emotive and Cognitive-behavior Therapy, 20(1), s.65-71.

Dryden, W. (1994). Reason and Emotion in Psychotherapy: Thirty Years on. Journal of Rational-emotive and Cognitive-behavior therapy, 12(2), s. 83-99.

Eisenberger, R., Huntingon, R., Hutchison, S., Sowa, D. (1986). Perceived Organizational Support. Journal of Applied Psychology, 71(3), s. 500-507.

Eisenberger, R. Fasolo, P. Davis-Lamastro, V. (1990), Perceived Organizational Support and Employee Diligence, Commitment, and Innovation. Journal of Applied Psychology, 75, s.51-59.

Erdoğan, İ. (1996). İşletme Yönetiminde Örgütsel Davranış. İstanbul Üniversitesi İşletme Fakültesi.

Hackman, J. R. ve Oldham, G. R. (1975). Development of the Job Diagnostic Survey. Journal of Applied psychology, 60(2), s.159.

İbicioğlu, H. ve Çağlar, N. (2015). İşletmelerde İnsan Gücü Verimliliğinin Arttırılmasında Örgüt İçin İletişimin Rolü. Dumlupinar Üniversitesi Sosyal Bilimler Dergisi, (2), s.171-185.

Jalagat Jr, R. (2016). Job Performance, Job Satisfaction, and Motivation: A Critical Review of their Relationship. International Journal of Advances in Management and Economics. 5(6), s.36-42.

Kesim, E. (2005). Bir Etik Davranış İlkesi Olarak Hesap Verebilirlik (Hesap Verme Sorumluluğu). Siyasette ve Yönetimde Etik Sempozyumu, s.269-281.

Koopmans, P. C., Sanderman, R., Timmerman, I., \& Emmelkamp, P. M. (1994). The Irrational Beliefs Inventory (IBI): Development and psychometric evaluation. European Journal of Psychological Assessment, 10(1), s.15-27.

Özdevecioğlu, M. (2013). Algılanan Örgütsel Destek ile Örgütsel Bağllılı Arasındaki İlişkilerin Belirlenmesine Yönelik Bir Araştırma. Dokuz Eylül Üniversitesi İktisadi İdari Bilimler Fakültesi Dergisi, 18(2), s.113-130.

Polatçı, S., Ardıç, K. ve Koç, M. (2014). Farklı Bir Bakış Açısından İş ve Yaşam Doyumu Algılanan Örgütsel Destek ve Örgütsel Bağlllığın Etkileri. Çukurova Üniversitesi Sosyal Bilimler Enstitüsü Dergisi, 23(1), s.267287.

Polatçı, S. (2015). Örgütsel ve Sosyal Destek Algılarının Yaşam Tatmini Üzerindeki Etkisi: İş ve Evlilik Tatmininin 
Aracılık Rolü. Ekonomik ve Sosyal Araştırmalar Dergisi, 11(2), s.25-44.

Rhoades, L. ve Eisenberger, R. (2002). Perceived Organizational Support: A Review of the Literature. Journal of Applied Psychology, 87(4), s.698.

Robbins, S. P., Judge, T. A., \& Vohra, N. (2013). Organizational Behavior, Pearson.

Szentagotai, A., Schnur, J., Digiuseppe, R., Macavei, B., Kallay, E. ve David, D. (2005). The Organization and the Nature of Irrational Beliefs: Schemas or Appraisal?. Journal of Cognitive and Behavioral Psychotherapies, 5(2). s.139-158.

Tanhan, F. (2014). Öğretmenlerde İrrasyonel İnançlar İle Cinsiyet ve Depresyon İlişkisinin İncelenmesi. Sakarya Üniversitesi Eğitim Fakültesi Dergisi, (28), s.55-73.

Weinberg, A. ve Doyle, N. (2017). Psychology at Work: Improving Wellbeing and Productivity in the Workplace. British Psychological Society.

Wethington, E. ve Kessler, R. C. (1986). Perceived Support, Received Support, and Adjustment to Stressful Life Events. Journal of Health and Social behavior, s.78-89. 